\title{
PEMBANGUNAN SISTEM CERDAS AGREGATOR BERITA BAHASA INDONESIA
}

\author{
Masayu Leylia Khodra ${ }^{1}$, Yudi Wibisono ${ }^{2}$, Ahmad Fauzan ${ }^{3}$, Bagus Rahman $^{4}$ \\ 1,3,4 Teknik Informatika, Sekolah Teknik Elektro dan Informatika, Institut Teknologi Bandung \\ ${ }^{2}$ Ilmu Komputer, Fakultas Pendidikan Matematika dan Ilmu Pengetahuan Alam, Universitas Pendidikan \\ Indonesia \\ ${ }^{1}$ masayu@stei.itb.ac.id, ${ }^{2}$ yudi@upi.edu, ${ }^{3}$ 13510004@std.stei.itb.ac.id, ${ }^{4}$ bagus.axel@gmail.com
}

\begin{abstract}
Abstrak
Sistem agregator berita, seperti news.google.com, dapat membantu pembaca berita dalam menghadapi ledakan informasi. Walaupun sistem agregator ini telah mengumpulkan artikel berita dari berbagai sumber dan menyajikannya pada satu tempat, pembaca masih menghadapi persoalan banyaknya informasi yang harus diproses, dan sebagian informasi menyatakan hal yang sama dengan kalimat yang berbeda. Untuk itu, diperlukan sistem agregator berita yang tidak hanya dilengkapi fasilitas crawling (pengumpulan berita secara otomatis dari berbagai situs berita online), tetapi juga dilengkapi berbagai fasilitas analisis teks (klasifikasi, clustering, ekstraksi informasi $5 \mathrm{~W} 1 \mathrm{H}$, dan peringkasan otomatis dari kumpulan artikel berita). Saat ini, belum ada sistem agregasi berita yang dilengkapi fasilitas peringkasan, terutama untuk berita Bahasa Indonesia. Sistem cerdas agregator berita ini terdiri atas 6 komponen utama yaitu 1) crawler untuk mengumpulkan berita terbaru, 2) $5 \mathrm{~W} 1 \mathrm{H}$ extractor untuk mengekstraksi informasi $5 \mathrm{~W} 1 \mathrm{H}$ (Who, What, Where, When, Why, How) dari setiap artikel berita, 3) classifier untuk kategorisasi jenis berita, 4) clusterer untuk mengelompokkan topik dari setiap jenis berita, 5) summarizer untuk meringkas kumpulan berita setiap topik, dan 6) penyaji antarmuka. Semua komponen analisis teks terutama $5 \mathrm{~W} 1 \mathrm{H}$ extractor dan summarizer merupakan kontribusi makalah ini yang membedakannya dengan penelitian sistem agregasi berita sebelumnya.
\end{abstract}

Kata kunci : sistem cerdas, agregator berita, bahasa Indonesia, 5W1H extractor, peringkasan kumpulan berita

\section{Pendahuluan}

Dengan semakin meningkatnya jumlah pengguna internet di Indonesia yaitu sebanyak 63 juta dari 240 juta penduduk Indonesia [2], terjadi transisi pola baca masyarakat dari berita media cetak ke media online. Berdasarkan survei terhadap para pengguna internet di Indonesia, internet paling banyak dimanfaatkan untuk pencarian informasi berita, yaitu mencapai $70.65 \%$ responden [3]. Namun, banyaknya situs berita online dapat menimbulkan masalah bagi pembaca berita. Jika pembaca tidak memiliki prioritas kebutuhan informasi yang spesifik dalam melakukan eksplorasi suatu topik berita, pembaca tersebut akan menerima informasi yang terlalu banyak pada waktu yang terbatas yang disebut information overload [14], yaitu ketidakmampuan manusia dalam memahami dan memproses semua informasi yang didapatkan [5]. Karena pembaca berita merupakan pemroses informasi dengan kemampuan kognitif yang terbatas
[18] dan dua per tiga konten berita sering diabaikan pembaca [6], beberapa informasi penting dalam berita terlewatkan. Pembaca berita biasanya mencari beberapa artikel berita yang mirip untuk mendapatkan semua informasi penting tersebut dengan lengkap. Dalam kegiatan ini, pembaca berita online akan mendapatkan beberapa artikel yang memiliki overlapping content [11] karena informasi penting yang sama ditulis dengan kalimat yang berbeda pada beberapa artikel.

Adanya agregator berita dapat membantu pembaca karena aplikasi ini mengumpulkan informasi berita dari berbagai sumber dan menyajikannya dalam satu tempat. Aplikasi agregator berita mengumpulkan berita terbaru dalam setiap waktu melalui RSS feed. Dengan agregator berita, pembaca tidak perlu lagi mencari berita, dan aplikasi mengambil berita sesuai kebutuhan dari pembaca [15]. Namun, agregator berita tidak mengurangi waktu pembaca untuk tetap membaca setiap artikel berita. Agregator berita hanya memilih 
salah satu artikel berita representatif dari suatu topik, lalu menampilkan beberapa kalimat pertama dari artikel tersebut. Pembaca masih menghadapi persoalan banyaknya informasi yang harus diproses, dan sebagian informasi menyatakan hal yang sama (redundan) yang disajikan dengan kalimat yang berbeda. Salah satu solusi persoalan informasi yang redundan adalah peringkasan multidokumen yang memberikan satu ringkasan untuk kumpulan dokumen yang mirip dan memiliki overlapping content.

Berbeda dengan agregator berita konvensional yang hanya menyajikan daftar topik berita dan kumpulan berita dari setiap topik, makalah ini bertujuan mendeskripsikan agregator berita yang dilengkapi dengan fasilitas analisis teks meliputi kategorisasi berita, clustering berita, ekstraksi informasi 5W1H (Who, What, Where, When, Why, How), dan peringkasan kumpulan berita. Kedua fitur fungsional tersebut merupakan fasilitas tambahan selain fitur fungsional umum agregator berita konvensional (yaitu crawling).

Ekstraksi informasi merupakan proses menstrukturkan informasi dari dokumen tidak terstruktur. Artikel berita merupakan dokumen yang tidak terstruktur, sedangkan $5 \mathrm{~W} 1 \mathrm{H}$ merupakan frame informasi terstruktur yang akan menjadi target ekstraksi informasi dalam penelitian ini. Dua pendekatan umum untuk ekstraksi informasi adalah pendekatan berbasis aturan dan pendekatan berbasis pembelajaran [9].

Peringkasan didefinisikan sebagai proses transformasi reduktif dari teks sumber ke teks ringkasan melalui reduksi teks dengan cara seleksi dan/atau generalisasi pada informasi yang penting dalam sumber [10-11]. Peringkasan kumpulan dokumen yang dilakukan dalam penelitian ini berbasis aspek informasi $5 \mathrm{~W} 1 \mathrm{H}$.

Saat ini, belum ada agregator berita yang dilengkapi fasilitas ekstraksi informasi ataupun peringkasan terpandu secara otomatis. McKeown dkk [17] telah mengembangkan Columbia Newsblaster sebagai sistem agregasi berita yang dilengkapi dengan fitur peringkasan multidokumen, tetapi sistem ini belum pernah diaplikasikan untuk bahasa Indonesia. Oleh karena itu, kontribusi dari makalah ini adalah: (1) desain framework agregator berita yang dilengkapi fasilitas ekstraksi informasi $5 \mathrm{~W} 1 \mathrm{H}$ dan peringkasan berbasis ekstraksi informasi $5 \mathrm{~W} 1 \mathrm{H}$; dan (2) mengaplikasikan berbagai task text mining pada kumpulan artikel berita bahasa Indonesia di dalam agregator berita.

Pada bagian selanjutnya, akan dibahas kajian terkait sistem agregasi berita dan peringkasan terpandu yang sudah ada. Bagian 3 akan membahas rancang bangun yang didesain untuk sistem agregasi berita dengan peringkasan terpandu. Pada bagian terakhir, akan dibahas konklusi dan penelitian selanjutnya yang akan dilakukan.

\section{Kajian Terkait}

Sebuah sistem agregasi berita merupakan situs yang mengambil berita beberapa situs berita online lainnya dan menampilkannya pada satu tempat. Isbel dkk [8] mengelompokkan sistem ini ke dalam empat kategori yaitu feed aggregators (seperti Yahoo! News dan Google News), speciality aggregators (seperti Techmeme), user-curated aggregators (seperti Digg), dan blog aggregators (seperti Gawker). Makalah ini akan mendesain framework untuk agregator berita kategori feed aggregators untuk Bahasa Indonesia.

Secara umum, agregator berita memiliki fitur kategorisasi berita, fitur pengelompokan berita (clustering) untuk mendapatkan topik per kategori, dan fitur penyajian. Karhendana [12] telah mengimplementasikan sistem Agata, sistem agregasi berita berbahasa Indonesia, tetapi sistem ini hanya memiliki fitur konvensional dan belum memiliki fasilitas peringkasan. McKeown dkk [17] telah mengembangkan Columbia Newsblaster sebagai sistem agregasi berita yang dilengkapi dengan fitur peringkasan multidokumen. Seperti yang telah dijelaskan pada bagian Pendahuluan, Columbia Newsblaster belum mempertimbangkan informasi yang telah diketahui pembaca dari artikel yang telah dibaca sebelumnya.

Dalam ekstraksi informasi, informasi terstruktur yang diekstrak dari dokumen yang tidak terstruktur dapat berupa entitas ataupun relasi antar entitas. Secara umum, entitas dapat berupa orang, perusahaan, organisasi, atau lokasi. Oleh karena itu, kegiatan utama dalam ekstraksi informasi adalah pengenalan entitas (named-entity recognition) dan ekstraksi relasinya [9]. Pengenalan entitas dapat dilakukan dengan memanfaatkan pola kemunculan entitas tersebut pada teks. Pola ini dapat didefinisikan secara manual oleh pakar ataupun didapatkan secara otomatis dengan pembelajaran mesin. Oleh karena itu, terdapat dua pendekatan dalam pengenalan entitas, yaitu pendekatan berbasis aturan dan pendekatan berbasis pembelajaran [9]. Setelah pengenalan entitas selesai dilakukan, kegiatan berikutnya adalah ekstraksi relasi antar entitas. Dengan mendefinisikan relasi semantik yang mungkin, entitas menjadi argumen dari relasi tersebut. Pendekatan yang paling umum dalam ekstraksi relasi adalah klasifikasi [9]. Berbagai pendekatan dibedakan oleh fitur yang digunakan [7]. Ekstraksi informasi berbasis model klasifikasi dari tweet bahasa Indonesia telah diaplikasikan [7, 13].

Mani dan Maybury [16] mendefinisikan empat pendekatan peringkasan teks. Pertama, pendekatan klasik melakukan pemberian bobot terhadap setiap 
unit teks menggunakan fitur dasar (seperti kata signifikan, lokasi, frasa petunjuk, kata judul), dan memilih unit teks dengan bobot tertinggi untuk membentuk ringkasan. Kedua, pendekatan berbasis koleksi mengkombinasikan beberapa fitur dasar dan memberikan bobot setiap fitur secara otomatis berdasarkan hasil pembelajaran koleksi. Pendekatan ini merupakan pendekatan yang paling populer untuk Bahasa Indonesia. Ketiga, pendekatan berbasis discourse memanfaatkan struktur discourse baik di level entitas teks maupun di level discourse. Barzilay dan Elhadad [4] menggunakan teknik perhitungan lexical chains untuk teks, dan melakukan analisis tingkat kepentingan kalimat berdasarkan lexical chains tersebut. Terakhir, pendekatan berbasis pengetahuan melakukan ekstraksi informasi berdasarkan template untuk menstrukturkan informasi pada teks, dan melakukan inferensi pengetahuan untuk menghasilkan ringkasan.

\section{Sistem Cerdas Usulan}

Dalam agregator berita yang diusulkan, sistem menyajikan daftar topik dan ringkasan dari kumpulan berita setiap topik. Seperti yang ditampilkan pada Gambar 1 untuk setiap kategori, ditampilkan maksimum lima topik berita.

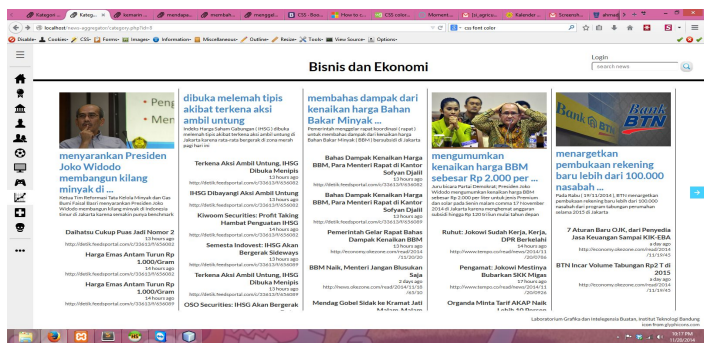

Gambar 1. Antarmuka halaman kategori dari Indonesian agregator berita yang diusulkan

Untuk setiap topik berita dari suatu kategori, ditampilkan ringkasan terpandu yang berisi informasi penting yang muncul berulang dalam beberapa artikel dan informasi unik yang dimiliki oleh artikel tertentu. Ringkasan terpandu ini merupakan ringkasan update yang berisi informasi terbaru dari artikel yang belum dibaca dengan mempertimbangkan konten dari ringkasan topik tersebut untuk kumpulan artikel yang telah dibaca sebelumnya. Setelah bagian ringkasan, ditampilkan daftar artikel berita dari setiap topik. Artikel yang telah dibaca ditandai dengan $\checkmark$ di depan judul berita tersebut.

Pengguna dapat memilih salah satu cluster untuk mendapatkan informasi yang lebih detil. Pada halaman cluster ini (lihat Gambar 2), setiap artikel berita dilengkapi dengan hasil ekstraksi $5 \mathrm{~W} 1 \mathrm{H}$.

Untuk memberikan keluaran seperti yang diberikan Gambar 1 dan Gambar 2, sistem agregasi berita usulan makalah ini terdiri atas enam komponen utama yaitu crawler \& HTML parser, $5 \mathrm{~W} 1 \mathrm{H}$ extractor, classifier, clusterer, summarizer, dan penyaji antarmuka. Selain itu, sistem ini memerlukan tiga basisdata yaitu basisdata berita yang menyimpan semua informasi dan teks berita, basisdata hasil yang menyimpan semua hasil klasifikasi, clustering, dan peringkasan, serta basisdata pengguna yang menyimpan log interaksi pengguna dengan sistem terutama artikel yang telah dibaca oleh setiap pengguna. Framework sistem ditunjukkan secara lengkap pada Gambar 3.

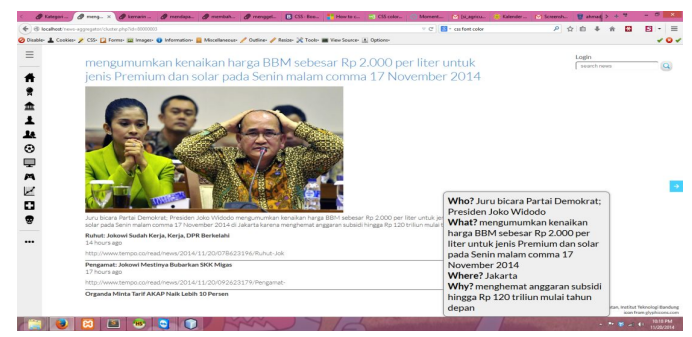

Gambar 2. Pada halaman cluster, informasi 5W1H ditampilkan untuk artikel yang dipilih

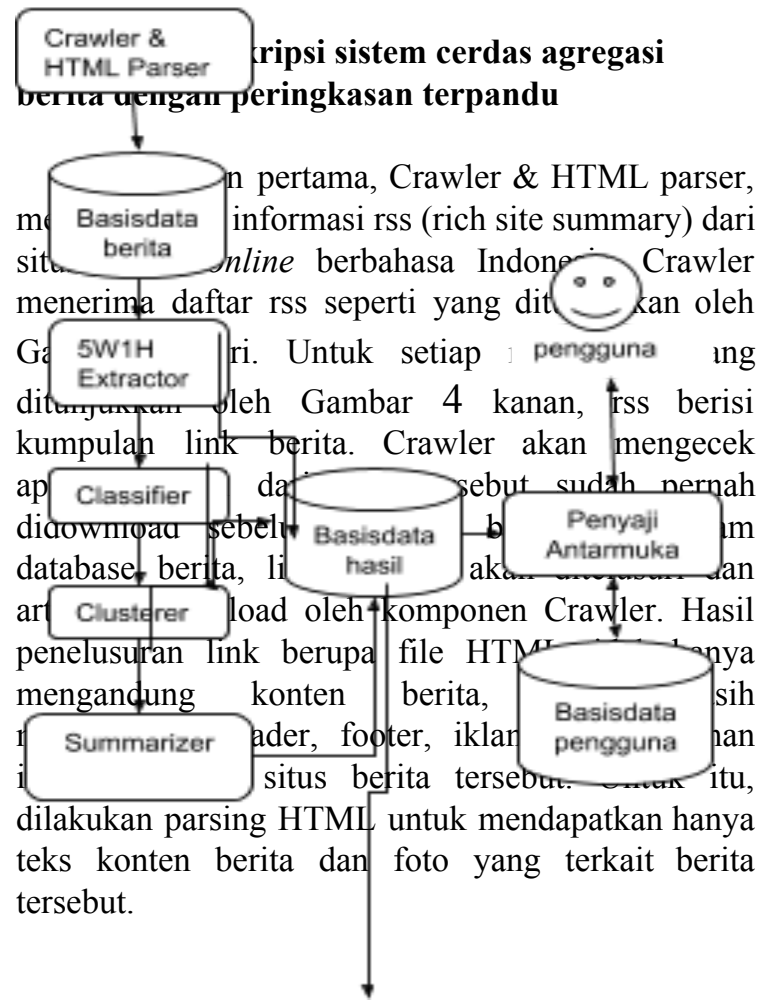


1 http://rss. detik. com/nindex, pho/detikcom 2 hittp://rss.detik.com/index.php/finance 3 http://rss. detik. com/index.php/hot 4 http: ///rss. detik. com/index.php/inet 5 http://rss. detik, com/index.php/sport/ 6 hitt: //rss.detik.com/index.php/otomo 7 http://rss. detik.com/index.php/food 8 http://rss. detik.com/index.php/health 9 http://rss.detik.com/index.php/trave 10 http://rss. detik.com/index.php/bandung 11 http://tempo.co/rss/terkin 2 htt: //tempo.co/rss/bisnis 3 http://tempo.co/rss/olahraga_sepakbol 14 http://tempo,co/rss/gayahidup 5 http://tempo.co/rss /internasion 16 http://tempo.co/rss/metro 7 http://tempo.co/rss/nasional 18 http://tempo.co/rss/olahrag $19 \mathrm{http:} / /$ tempo.co/rss/teknolog hitti:/ /tempo co/sss perita pith (1) 22 http://rss, vivanews. com/get/pot

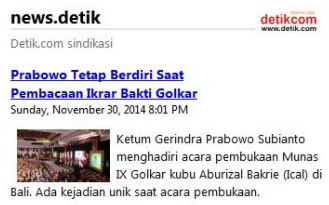

Gambar 4. Input dari crawler: (kiri) daftar rss; (kanan) contoh rss

Komponen kedua, 5W1H Extractor, berfungsi untuk mendapatkan informasi terstruktur $5 \mathrm{~W} 1 \mathrm{H}$ dari setiap teks konten berita yang tidak terstruktur. Dalam ekstraksi informasi ini, hanya dilakukan ekstraksi entitas dengan menggunakan pendekatan sequence labeling [1]. Terdapat 6 jenis informasi yang akan diekstraksi dari setiap artikel berita yaitu Who, What, Where, When, Why, How. Dengan menggunakan notasi BIO (Begin In Other), setiap jenis informasi terdiri atas dua kategori yaitu kategori begin- $<$ jenis informasi $>$ untuk token pertama yang mengandung informasi tersebut dan in- $<$ jenis informasi $>$ untuk token kedua dan berikutnya yang mengandung informasi tersebut. Kategori tambahan other didefinisikan untuk token lain yang tidak berlabel. Total kategori untuk 6 jenis informasi yang telah didefinisikan tersebut adalah $6 * 2+1=13$ kategori. Model klasifikasi akan menganalisis setiap token pada artikel dan menentukan kategori token tersebut. Berikut merupakan contoh potongan artikel pada korpus yang setiap tokennya telah ditentukan kategorinya.

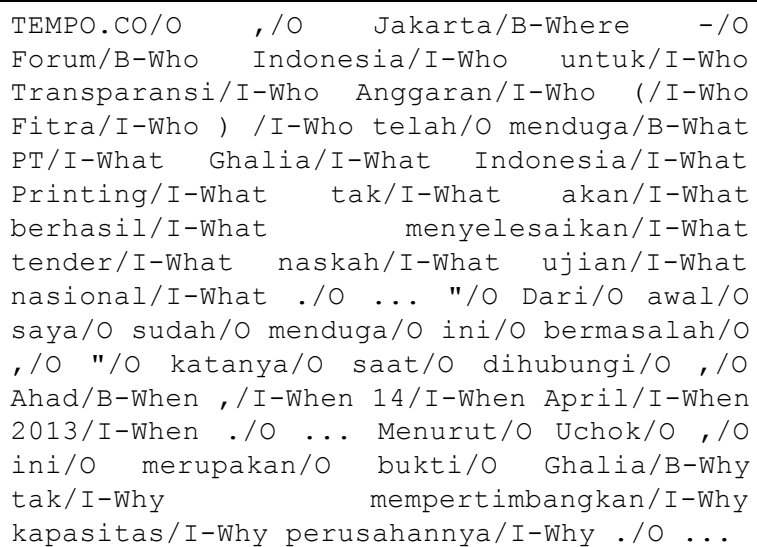

Pada potongan artikel di atas, terdapat 5 jenis informasi yaitu Who, What, Where, When, Why. Token pertama setiap informasi mendapat awalan B (begin) seperti kategori B-Who, dan B-What. Jika informasi tersebut mengandung lebih dari satu token, kategori yang digunakan diawali dengan I (in) seperti I-When. Vektor fitur untuk token didefinisikan berdasarkan atribut leksikal token tersebut dan 2 atribut token tetangganya (2 sebelum dan 2 sesudah).

\begin{tabular}{|c|c|}
\hline 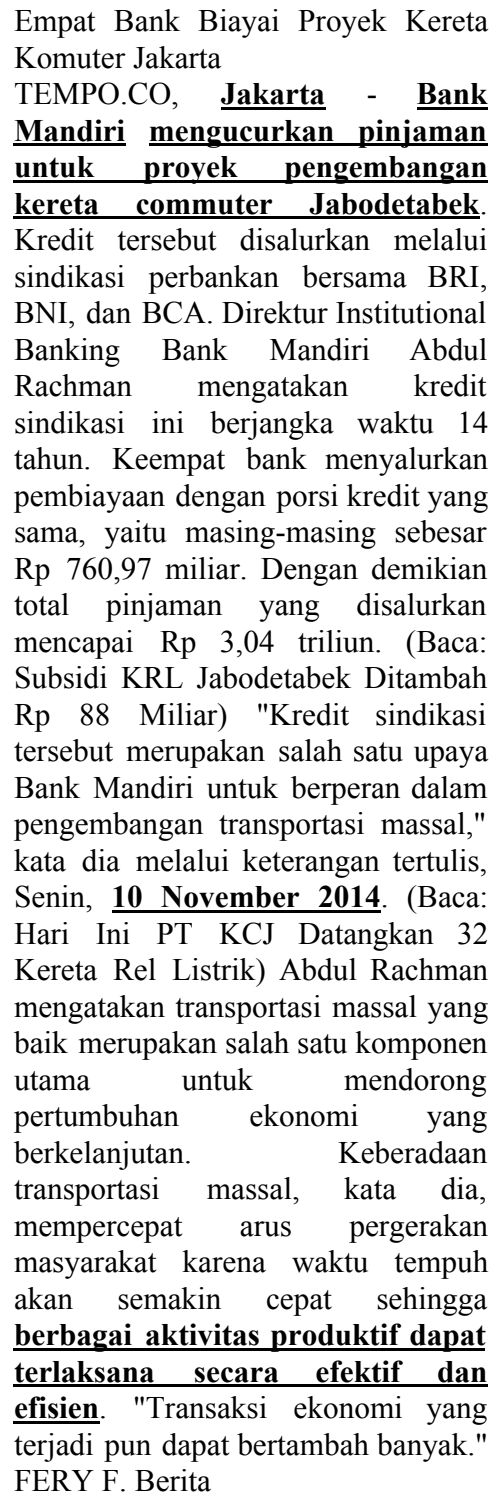 & 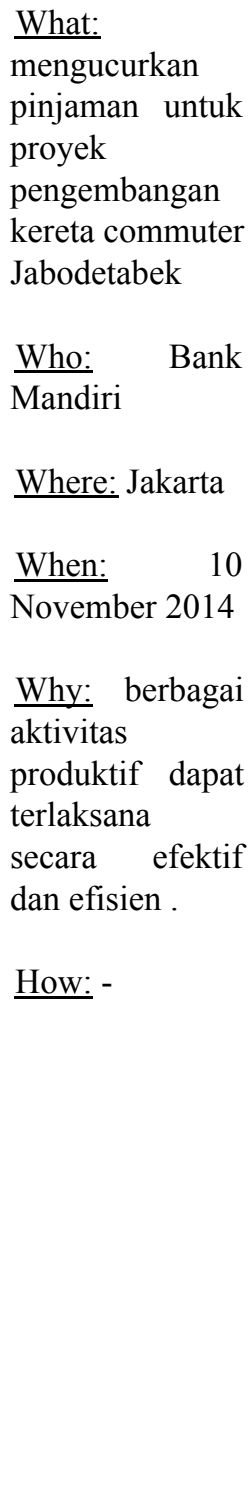 \\
\hline
\end{tabular}

Komponen ketiga, Classifier, berfungsi menentukan kategori dari setiap artikel berita. Beberapa situs telah menentukan kategori dari setiap artikel beritanya, tetapi informasi ini tidak dapat diakses melalui RSS. Selain itu, label kategori dapat berbeda antar situs media online. Oleh karena itu, makalah ini menggunakan 10 kategori berita yaitu pendidikan, politik, hukum dan kriminal, sosial budaya, olahraga, teknologi dan sains, hiburan, bisnis dan ekonomi, kesehatan, bencana dan kecelakaan. Seperti 5W1H Extractor, classifier dibangun dengan menggunakan pendekatan 
pembelajaran mesin dari korpus dokumen berlabel kategori yang telah didefinisikan.

Komponen keempat, Clusterer berfungsi mengelompokkan kumpulan berita dalam setiap kategori yang sama untuk mendapatkan topik-topik utamanya. Pada Gambar 1, ditunjukkan lima topik utama dari kategori Bisnis dan Ekonomi. Pada makalah ini, algoritma clustering yang digunakan adalah kMeans dengan $\mathrm{k}=5$. Untuk pemberian label cluster, dilakukan pencarian medoid dari centroid akhir setiap cluster, lalu diambil judul dari artikel medoid tersebut.

Komponen Summarizer menghasilkan ringkasan untuk setiap topik. Pada sistem saat ini, ringkasan dibentuk dengan membentuk kalimat berdasarkan template informasi 5W1H dari medoid.

Komponen Penyaji Antarmuka berfungsi untuk menampilkan berita dan hasil analisis berita dari subsistem back-end (semua komponen lainnya) yang disimpan pada basis data hasil. Subsistem front-end ini dikembangkan sebagai aplikasi berbasis web dengan menggunakan bahasa PHP, javascript dan HTML, dan skema MVC (Model-View-Controller). Terdapat 8 fitur utama untuk bagian front-end ini. Seperti yang ditunjukkan oleh Tabel 1, kedelapan fitur telah berhasil diimplementasikan dan memberikan hasil sesuai spesifikasi berdasarkan kasus uji yang diberikan. Gambar 1 dan Gambar 2 merupakan contoh antarmuka yang ditampilkan untuk fitur 3 (Melihat Kategori) dan 4 (Melihat Cluster). Fitur 1,2,6,7,8 merupakan fitur tambahan untuk sistem agregator berita ini.

Tabel 1. Hasil pengujian setiap fitur

\begin{tabular}{|l|l|l|}
\hline No. & Fitur & Pengujian \\
\hline 1 & Login & Berhasil \\
\hline 2 & Register & Berhasil \\
\hline 3 & Melihat Kategori & Berhasil \\
\hline 4 & Melihat Cluster & Berhasil \\
\hline 5 & Melihat Berita & Berhasil \\
\hline 6 & Log & Berhasil \\
\hline 7 & Monitoring & Berhasil \\
\hline 8 & Melakukan Pengaturan & Berhasil \\
\hline
\end{tabular}

\section{Konklusi}

Makalah ini telah menjelaskan sistem cerdas agregator berita yang terdiri atas 6 komponen utama yaitu crawler, 5W1H extractor, classifier, clusterer, summarizer, dan penyaji antarmuka. Sistem cerdas ini memanfaatkan berbagai model klasifikasi berbasis pembelajaran mesin.

Penelitian selanjutnya akan fokus untuk mengevaluasi model yang ada, dan membangun berbagai model yang lebih baik dengan menggunakan set fitur dan algoritma pembelajaran yang berbeda.

\section{Daftar Pustaka:}

[1] Aggarwal, C.C., Zhai, C. (2012). Mining Text Data. Springer.

[2] APJII (2012). Asosiasi Penyelenggara Jasa Internet Indonesia: Statistik Indonesia Internet Users.

[3] APJII (2013). Statistik Indonesia Internet Users.

[4] Barzilay, R., Elhadad, M. (1999). Using Lexical chain for Text Summarization. Proceedings of the ACL Workshop on Intelligent Scalable Text Summarization.

[5] Elwart, S. (2013). Information Overload Making Your Head Explode? WND Education

[6] Graber, D. (1984). Processing the news: How people tame the information tide. New York: Longman.

[7] Hasby, M., Khodra, M.L. Optimal Path Finding based on Traffic Information Extraction from Twitter. Prosiding International Conference on ICT for Smart Society 2013. Jakarta. 2013.

[8] Isbell, K. (2010). The Rise Of The Agregator berita: Legal Implications And Best Practices. The Berkman Center for Internet \& Society at Harvard University.

[9] Jiang, J. Information Extraction from Text, in Mining Text Data. Springer. 2012.

[10] Jones, K. S. (1999). Automatic Summarizing : Factors and Directions. In I. Mani, \& M. T. Maybury (Eds.), Advances in Automatic Text Summarization (pp. 1-12). London: MIT Press.

[11] Jones, K. S. (2007) : Automatic Summarising: The state of the art. Information Processing and Management 43 (2007) 1449-1481, Elsevier.

[12] Karhendana, A. (2008). Pemanfaatan Document Clustering Pada Agregator Berita. Laporan Tugas Akhir Program Studi Teknik Informatika STEI ITB, Institut Teknologi Bandung, Bandung.

[13] Khodra, M.L., Purwarianti, A. (2014). Ekstraksi Informasi Transaksi Online di Indonesia pada Twitter. Jurnal Cybermatika $1 / 1 / 2013$.

[14] Larson, P.D., Kulchitsky, J.D. (2007). Information Overload: Too Much of a Good Thing? 92 Annual International Supply Management Conference, May 2007.

[15] Lasica, J. (2003, January 23). News That Comes to You. Retrieved from USC Annenberg Online Journalism Review

[16] Mani, I., Maybury, M.T. (1999): Advances in Automatic Text Summarization. MIT Press.

[17] McKeown, K. R., Barzilay, R., Evans, D., Hatzivassiloglou, V., Klavans, J. L., Nenkova, A. (2002). T racking and Summarizing News on a Daily Basis with Columbia's Newsblaster. 
Proceedings of the second international conference on Human Language Technology Research (pp. 280-285). Morgan Kaufmann Publishers Inc.

[18] Opgenhaffen, M., d'Haenens, L. (2011). The Impact of Online News Features on Learning from News: A Knowledge Experiment. International Journal of Internet Science, 2011, $6(1), 8-28$. 
